\title{
ZERO DISCHARGE COMPOSTING OF PALM OIL MILL WASTES
}

(Date received:17.2.09/Date accepted:6.7.11)

\author{
Ooi Ho Seng ${ }^{1}$ \\ O3 Solutions Sdn Bhd. E3303, 3 Two Square, 2 Jalan 19/1, \\ 46300 Petaling Jaya, Selangor \\ Email: ${ }^{1}$ O3soln@gmail.com
}

\section{ABSTRACT}

The conventional methods of disposal and treatment of oil palm mill wastes are not environmentally friendly and they result in large amount of Greenhouse gases being emitted into the atmosphere. The technical feasibility of setting up a compost plant to use up all the palm oil mill wastes to produce compost was evaluated at FELDA Jengka 21 where the palm oil mill has been upgraded to use the new Eco-D two-phase decanter system instead of the conventional three-phase decanter system and the conventional batch steriliser system has been replaced by the continuous steriliser system. The result of the composting trials showed that the C:N ratios of the sieved compost materials was less than 20 after 30 days while the average $C: N$ ratios of the compost materials were still above 30. Based on the results of the composting trial, all the POME produced by the palm oil mill can be used up in the compost plant.

Keywords: EFB, Microbes, POME, Zero Discharge Composting

\subsection{INTRODUCTION}

\subsection{Background}

According to MPOB (2007), about 80 million tonnes fresh fruit bunches (FFB) were processed in 2006 and the amount of palm oil mill wastes produced were 17.4 million tonnes of EFB, 53.1 million tonnes POME, 10.7 million tonnes of mesocarp fibre, 4.3 million tonnes of kernel shell and 2.8 million tonnes of decanter solids. Most of the mesocarp fibres and kernel shell were used as boiler fuels to produce steam for FFB sterilisation and for generation of electricity using the steam turbines. About 2.0 million tonnes of ash was produced annually from the burning of the mesocarp fibres and kernel shell in the boilers. Some EFB were used for soil mulching in the oil palm plantations and that helped to reduce the input of inorganic nutrients and to increase the organic content of the soil. Some EFB were shredded and used as boiler fuel. However, most of the EFB, the other mill solid wastes and boiler ash were dumped in the landfills.

POME is biologically treated using the conventional Effluent Treatment Ponds before it is being discharged into water courses or being used for land irrigation. The conventional methods of palm oil mill wastes treatment and disposal are however not environmentally-friendly and they result in large amount of Greenhouse gasses such as methane gas being emitted into the atmosphere (Ooi et al, 2007).

Many palm Oil mills have recently upgraded their oil room operations by installing the Eco-D two-phase decanter system (Kumar et al, 2007), producing significantly less POME as presented in Table 1. The total amount of liquid wastes (or POME) produced is about $45 \%$ to FFB, comprising $20 \%$ to FFB of Slurry, $15 \%$ to FFB of Condensate and $10 \%$ to FFB of Wash Water. The total amount of liquid wastes produced by the upgraded mill can be reduced further to 0.25 ton POME per ton FFB by replacing the conventional batch steriliser system with the continuous steriliser system as shown in Table 1.

The efficiency and effectiveness of the various processes and operations of the compost plant can be significantly enhanced if they are well integrated with the processes and operations of the palm oil mill. Considering the huge amount of solid and liquid wastes that are produced by the palm oil mill daily, the compost plant is usually located next to the mill to reduce the costs of handling the mill wastes. If all the liquid wastes of the palm oil mill can be utilised in the compost plant, then the mill owner can operate the mill without the conventional POME treatment ponds.

Table 1: Amount of wastes produced by palm oil mill

\begin{tabular}{|l|c|c|c|}
\hline \multirow{2}{*}{$\begin{array}{c}\text { Mill } \\
\text { Wastes }\end{array}$} & $\begin{array}{c}\text { Conventional } \\
\text { Mill }\end{array}$ & $\begin{array}{c}\text { Mill with } \\
\text { Eco-D } \\
\text { System }\end{array}$ & $\begin{array}{c}\text { Mill with Eco-D } \\
\text { System \& Cont. } \\
\text { Steriliser }\end{array}$ \\
\cline { 2 - 4 } EFB to FFB & \% to FFB & \% to FFB \\
\hline POME & 23 & 23 & 23 \\
\hline $\begin{array}{l}\text { Decanter } \\
\text { Solid }\end{array}$ & 3.5 & 45 & 25 \\
\hline Boiler Ash & 2.5 & 2.5 & 2.5 \\
\hline
\end{tabular}

Source: Schuchardt (2008)

The commercial feasibility of a compost plant is dependent significantly on the rate of composting at the compost station. The duration of the composting process, which is dependent on 
rate of composting, determines the size of the composting plant and ultimately the cost of capital investments. The composting process can be successfully controlled by providing the right microbes at the right time and place; and by maintaining the right microenvironments ( $\mathrm{C}: \mathrm{N}$ ratio, moisture content, temperature, oxygen level) that are conducive for the different microbes to undertake the composting work throughout the whole composting process.

\subsection{Review of Related Composting Work}

Several palm oil mills in Malaysia and Indonesia are composting their EFB and POME commercially using the open field system (usually covered using membrane sheets when it rains). Due to the unpredictability and variation of the weather, the rate of composting and the quality of the compost produced are not consistent. The lack of control of the composting environment makes production planning and marketing of the compost difficult.

Composting studies by Suhami and Ong (2001) and Baharuddin et al (2009) were carried out in the open fields and not under the roof. The results obtained in the two studies were more or less similar except that slightly higher NPK (Nitrogen, Phosphorous and Potassium) values were reported in the latter (without the addition of chicken manure).

Chemical and biological laboratory analyses were carried out on the sieved compost samples in the two studies. Baharuddin et al (2009) reported the use of $2 \mathrm{~mm}$ sieve to obtain the compost samples.

The EFB-POME co-composting plant in Lahad Datu, Sabah is an indoor composting plant under the roof of about 2.2 ha in composting area (Ooi et al 2007). The composting period is 5055 days plus 20 days curing. Microbes are applied at the start of the composting process. Chicken dung is added to the composts, which are targeted for the commercial market, to increase their NPK values.

The purpose of the composting work affects the type of composting studies and laboratory analyses being undertaken. The composting trials by Suhaimi and Ong (2001) and Baharuddin et al (2009) were geared towards understanding the composting process. Meanwhile, palm oil millers in Indonesia and Sabah have ventured into composting the palm oil mill wastes on a commercial scale with the aim of qualifying as CDM projects. These composting projects are therefore geared towards reducing Green House Gases (especially methane gas) emission to earn Carbon Emission Reduction revenue.

The present composting trials is a preliminary study that is aimed at evaluating the technical feasibility of using the existing composting facility at Jengka 21 to undertake the composting of the wastes produced by the palm oil mill. The expected final outcome from a series of composting trials, in which the effects of various governing composting parameters are investigated, is an operating procedure that enables all the wastes produced by the palm oil mill to be used in the compost plant

\subsection{Objectives of Study}

a) To conduct the batch trials on co-composting of EFB and POME using the available cocktails of microbes

b) To investigate whether all the wastes produced by the palm oil mill can be used up in the compost plant.

\subsection{METHOD AND MATERIALS}

\subsection{The Compost Plant}

The present composting trials were carried out at FELDA Jengka 21 commercial compost plant. The $60 \mathrm{mt}$ per hour palm oil mill has been set up without the conventional Effluent Treatment Ponds. Water is added to the POME at the mill to dilute it and reduce its viscosity to facilitate pumping it from the mill to the POME Retention tank. The amount of solid and liquid wastes produced by the $60 \mathrm{tph}$ palm oil mill, that was currently running at $50 \%$ capacity, were as presented in the Table 2. For every metric ton of FFB (fresh fruit bunch) processed, the mill produces about $0.22 \mathrm{mt}$ of EFB (empty fruit bunch) and about $0.45 \mathrm{mt}$ of POME (palm oil mill effluent) after dilution.

Table 2: Amount of wastes produced by the palm oil mill

\begin{tabular}{|l|c|c|c|c|}
\hline & \multirow{2}{*}{$\begin{array}{c}\text { Estimated } \\
\text { BOD }\end{array}$} & $\begin{array}{c}\text { Mill Wastes } \\
\text { (\% FFB) }\end{array}$ & $\begin{array}{c}\text { Working Capacity } \\
(\mathbf{m t} \text { per day })\end{array}$ \\
\cline { 4 - 5 } & & & $\mathbf{5 0 \%}$ & $\mathbf{1 0 0 \%}$ \\
\hline FFB & & $\mathbf{2 2}$ & $\mathbf{1 3 2}$ & $\mathbf{2 6 4}$ \\
\hline EFB & 180,000 & 20 & 120 & 240 \\
\hline Eco-D slurry & & 15 & 90 & 180 \\
\hline Condensate & $<40,000$ & 10 & 60 & 120 \\
\hline Wash Water & $<5,000$ & $\mathbf{4 5}$ & $\mathbf{2 7 0}$ & $\mathbf{5 4 0}$ \\
\hline POME (Total) & & & & \\
\hline
\end{tabular}

There are 8 composting compartments and the size of each compartment is $20 \mathrm{~m} \times 50 \mathrm{~m}$. The shredded EFB is heaped up to $1.5 \mathrm{~m}$ in height and the total weight of the EFB is between 400 to $450 \mathrm{mt}$ per compartment. A gantry turner is used to turn the compost materials (see Plate 1). The total amount of POME that is used to spray on the shredded EFB in the composting is between 800 to $900 \mathrm{mt}$ per compartment. The amount of microbe solution to apply is 900 liters.

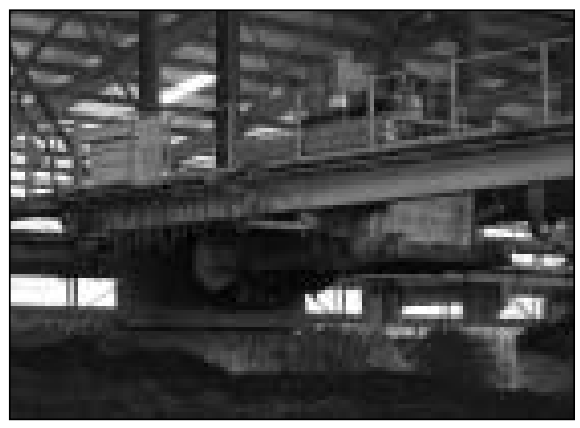

Plate 1: Gantry turner to mix compost materials

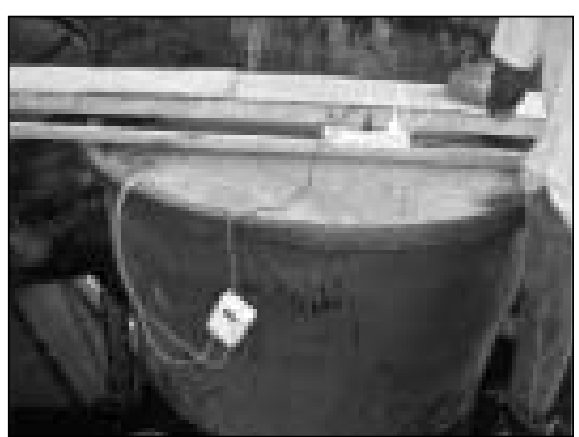

Plate 2: Preparation of microbe solutions 
2.2 Schedule of Activities

\begin{tabular}{|c|c|c|c|}
\hline Day & Activity & $\begin{array}{l}\text { POME } \\
\text { applied }\end{array}$ & $\begin{array}{l}\text { Compost } \\
\text { samples }\end{array}$ \\
\hline $1-4$ & $\begin{array}{l}\text { Load } 400 \mathrm{mt} \text { of } \\
\text { shredded and } \\
\text { pressed EFB into the } \\
\text { selected composting } \\
\text { compartment }\end{array}$ & & $\begin{array}{l}\text { Collect } 4 \text { compost } \\
\text { samples on day } 1\end{array}$ \\
\hline $1-7$ & $\begin{array}{l}\text { Apply POME on the } \\
\text { EFB for about } 45 \\
\text { to } 60 \text { minutes and } \\
\text { use the gantry turner } \\
\text { to turn the compost } \\
\text { heaps once a day }\end{array}$ & $150 \mathrm{mt}$ & $\begin{array}{l}\text { Collect } 4 \text { compost } \\
\text { samples on day } 7\end{array}$ \\
\hline $5-8$ & $\begin{array}{l}\text { Preparation of the } \\
\text { Microbe solution }\end{array}$ & & \\
\hline 8 & $\begin{array}{l}\text { Apply the microbe } \\
\text { solution uniformly } \\
\text { on the compost } \\
\text { heaps and use the } \\
\text { gantry turner to } \\
\text { turn and mix them } \\
\text { thoroughly }\end{array}$ & & \\
\hline $9-15$ & $\begin{array}{l}\text { Apply POME on the } \\
\text { EFB for } 60 \text { minutes } \\
\text { daily and then turn } \\
\text { the heap using the } \\
\text { gantry tuner } 2 \text { times } \\
\text { a day }\end{array}$ & $350 \mathrm{mt}$ & $\begin{array}{l}\text { Collect } 4 \text { compost } \\
\text { samples on day } 15\end{array}$ \\
\hline $16-22$ & $\begin{array}{l}\text { Apply POME on } \\
\text { EFB for } 60 \text { minutes } \\
\text { daily and turn } \\
\text { the heap using the } \\
\text { gantry tuner once } \\
\text { a day }\end{array}$ & $175 \mathrm{mt}$ & $\begin{array}{l}\text { Collect } 4 \text { compost } \\
\text { samples on day } 22\end{array}$ \\
\hline $20-23$ & $\begin{array}{l}\text { Preparation of the } \\
\text { Microbe solution }\end{array}$ & & \\
\hline 23 & $\begin{array}{l}\text { Apply the microbe } \\
\text { solution uniformly } \\
\text { on the compost } \\
\text { heaps and use the } \\
\text { gantry turner to } \\
\text { turn and mix them } \\
\text { thoroughly }\end{array}$ & & \\
\hline $24-30$ & $\begin{array}{l}\text { Apply POME on } \\
\text { EFB for } 60 \text { minutes } \\
\text { daily and turn the } \\
\text { heap using the } \\
\text { gantry tuner once } \\
\text { a day }\end{array}$ & $175 \mathrm{mt}$ & $\begin{array}{l}\text { Collect } 4 \text { compost } \\
\text { samples on day } 30\end{array}$ \\
\hline $31-86$ & $\begin{array}{l}\text { Turn the compost } \\
\text { daily using the } \\
\text { gantry turner }\end{array}$ & & $\begin{array}{l}\text { Collect } 4 \text { compost } \\
\text { samples on day } 37 \text {, } \\
44,51,58,65,72, \\
79,86\end{array}$ \\
\hline
\end{tabular}

Total POME $=850 \mathrm{mt}$

\subsection{Preparation of the Microbe Solution}

The procedure for the preparation of the Microbe Solution are as follows:

- Fill the 250 gallon water tank with 900 litres of un-chlorinated water

- $\quad$ Add in $5 \mathrm{~kg}$ of molasses (sugar)

- Mix the 4 litres of the bacterial solution into the water

- Aerate the water for 2-3 days to multiply the microbes

- On the third day, blend and mix the fungi cultures into the microbe solution

\subsection{Monitoring the Composting Process and the Microbial Population}

The monitoring of the oxygen levels, temperatures and moisture contents of the compost heaps and the turning of the compost heaps were undertaken daily. The progress of the composting process and the change in the microbial population were monitored over the entire composting period.

Compost samples were taken at weekly intervals and they were taken to Universiti Putra Malaysia for the chemical and biological laboratory analyses on the same day. Chemical laboratory analyses were also carried out on the sieved compost samples that wer taken on Day 22, Day 30 and Day 37.

\subsection{REPORT OF TEST RESULTS}

\subsection{Results of Composting Trial}

The Composting Trial was started in compartment BAY1 on 15 April 2009 and the TCS Microbe solution was applied on 22 April 2009. The second application of the microbe solution was carried out on 8 May 2009. The results of the trial are summarised and presented in the Table 3 . The detailed results of the laboratory analyses are presented in Appendix 1.

Table 3: Summarised results of composting batch trial

\begin{tabular}{|c|c|c|c|c|c|c|}
\hline Day & $\begin{array}{c}\text { POME } \\
\text { applied } \\
\text { (mt) }\end{array}$ & $\begin{array}{c}\text { Day to } \\
\text { take } \\
\text { Sample }\end{array}$ & $\begin{array}{c}\text { Date } \\
\text { Sample } \\
\text { Taken }\end{array}$ & $\begin{array}{c}\text { Moisture } \\
\text { Content } \\
\text { (\% w.b.) }\end{array}$ & $\begin{array}{c}\text { C:N } \\
\text { Ratio of } \\
\text { unsieved } \\
\text { Compost }\end{array}$ & $\begin{array}{c}\text { C:N } \\
\text { Ratio of } \\
\text { sieved } \\
\text { Compost }\end{array}$ \\
\hline 1 & - & 1 & $15 / 04 / 09$ & 50 & 54 & - \\
\hline $1-7$ & 150 & 7 & $22 / 04 / 09$ & 60 & 49 & - \\
\hline $8-15$ & 350 & 15 & $30 / 04 / 09$ & 68 & 36 & - \\
\hline $16-22$ & 175 & 22 & $06 / 05 / 09$ & 72 & 30 & 20 \\
\hline $23-30$ & 175 & 30 & $15 / 05 / 09$ & 71 & 33 & 16 \\
\hline $31-37$ & - & 37 & $20 / 05 / 09$ & 72 & 32 & 14 \\
\hline $38-44$ & - & 44 & $28 / 05 / 09$ & 69 & 36 & - \\
\hline $45-51$ & - & 51 & $03 / 06 / 09$ & 69 & 37 & - \\
\hline $52-58$ & - & 58 & $10 / 06 / 09$ & 65 & 32 & - \\
\hline $59-65$ & - & 65 & $17 / 06 / 09$ & 66 & 37 & - \\
\hline $66-79$ & - & 79 & $01 / 07 / 09$ & 53 & 32 & - \\
\hline $80-86$ & - & 86 & $08 / 07 / 09$ & 50 & 28 & - \\
\hline
\end{tabular}

\subsection{DISCUSSION OF TEST RESULTS}

The laboratory analyses of the compost samples showed that the moisture contents of the compost heaps varied from 68 to $72 \%$ wet basis between Day 16 and Day 37 (refer Table 3). 
They were above the optimum moisture range of 40 to $65 \%$. Water had displaced much of the air in the pore spaces of the composting materials when the moisture content was above $65 \%$ and air movement was inhibited. As the compost piles were too wet and the aeration was inadequate, the aerobic bacteria could not get enough oxygen and this had led to anaerobic conditions being created within the compost heaps.

Referring to Table 3, it is noted that the $\mathrm{C}: \mathrm{N}$ ratios of the unsieved compost samples did not changed much after 30 days, remaining around 30 . As the composting progress, more and more of the shorter decomposed EFB fibres were observed to settle lower and lower down within the compost heaps while the longer undecomposed fibres were observed to remain near the top of the compost heaps. The compost samples collected were observed to comprise a higher percentage of the longer undecomposed fibres after the 30 days as the shorter decomposed fibres had turned into dark powdery compost and had settled at the bottom of the compost heaps. The $\mathrm{C}: \mathrm{N}$ ratios of the sieved compost samples that were taken on Day 22, Day 30 and Day 37 were 20, 16 and 14 respectively

A typical conventional palm oil mill produces about $0.65 \mathrm{mt}$ POME and $0.23 \mathrm{mt}$ EFB for every metric ton of FFB processed. The palm oil mill at Jengka-21 had been specially upgraded by MODIPALM with the installation of the Continuous Sterilizer System and the two phase Eco-D Decanter System. The mill have reduced the mill wastes to $0.45 \mathrm{mt}$ of POME and $0.22 \mathrm{mt}$ of EFB for every metric ton of FFB processed. The reduction in the amount of POME produced by the mill has enabled all the POME to be used. In the composting trials, $850 \mathrm{mt}$ of POME was used up on $400 \mathrm{mt}$ of EFB. The longer EFB fibres were found to decompose much slower than the shorter EFB and they were sieved out and returned to the composting compartment for further composting.

The pollution that is caused by the conventional treatment and disposal of POME is more serious than those caused by the other mill wastes. Hence it is more important for all the POME produced to be used up in the compost plant. On the other hand, any excess EFB may be used as bio-fuel in the boilers. The composting trials results showed that all the POME produced by the mill can be used up in the existing Compost Plant.

The biological laboratory results (presented in Appendix 1) showed that the biological breaking down of the long EFB fibres by the Fungus and the Cellulolytic microbes was slow. Future work may be undertaken to examine if the composting process can be improved by cutting the EFB fibres to shorter lengths. The assumption is that if the lengths of the EFB fibres are shorter, a more uniform mixture throughout the compost heaps may be obtained when they are mixed with the POME. In addition, the microbes may be more uniformly distributed throughout the compost heaps.

\subsection{CONCLUSION}

The composting of EFB and POME was carried out at an existing compost plant and $\mathrm{C}: \mathrm{N}$ ratios of sieved compost materials of less than 20 were achieved after 30 days while the average $C: N$ ratios of the compost materials were still hovering around 30 . The most significant result of the composting trial is that all the POME that is produced by the mill can be used up in the Compost Plant.

\subsection{ACKNOWLEDGEMENT}

The composting trials were undertaken by O3 Solutions Sdn Bhd jointly with MODIPALM Sdn Bhd, FELDA, and UPM. My sincere thanks and appreciation goes to my colleague, Pn. Nor Ain J., who has assisted me in the trials. I am grateful to Dr C.S. Tan who supplied the TCS Microbes. I am thankful to Dr N.L. Chin, Ms. C.Y. Yeoh and Ms. Norazlin A. of UPM for conducting the weekly chemical and biological laboratory analyses of the compost samples. Last but not least, I would to thank Ms. Y.Y. Lee and Mr. Osman M.Y., UPM students on Industrial Training at O3 Solutions and Mr. Segar of MODIPALM Engineering Sdn Bhd for their assistance in implementing the composting trials.

\section{REFERENCES}

[1] Baharuddin A.S., Wakikasa M., Shirai Y., Abd-Azis S.,Abdul Rahman N.A., and Hassan M.A. (2009) Cocomposting of Empty Fruit Bunches and Partially Treated palm Oil Mill Effluent in Pilot Scale. Int. J. of Agri. Research 4(2), 69-78. 2009

[2] Kumar Subramaniam, Ooi Ho Seng and S. Thiagarajan (2007) Zero Waste Discharge Solution for Palm Oil Mills. Proceedings of 25th Conference of the ASEAN Federation of Engineering Organisations, held at Cebu City, Philippines, November 27-29, 2007.

[3] MPOB (2007). Overview Of The Malaysian Oil Palm Industry 2006. Website: http://econ.mpob.gov.my/ economy/EID_Review06.htm

[4] Ooi Ho Seng, Kumar Subramaniam and S. Thiagarajan (2007) Zero Waste Discharge from Palm Oil Mills. The Planters, Kuala Lumpur, 83 (979): 671-681

[5] Schuchardt,F, Wulfert K, and Tjahono Herawan (2008). Protect the environment and make profit from the waste in palm oil industry. Paper presented at W-POSE 2008 Conference held on 20-23 May 2008 at Jakarta Convention Center. IOPRI-GAPKI

[6] Suhaimi M and Ong HK (2001) Composting Empty Fruit Bunches of Oil Palm. The Food and Fertilizer Technology Centre (FFTC). http://www.agnet.org/ library/eb/505a/

\section{PROFILE}

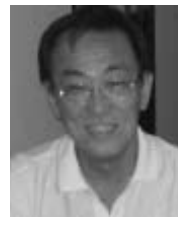

IR. OOI HO SENG graduated from the University of Malaya with a Bachelor of Engineering (Mechanical) degree in 1972 and a Masters of Engineering Science degree in 1975. Ir Ooi worked as a Research Officer in MARDI (Malaysian
Agricultural Research and Development Institute) from 1974 to 2005 and as a part-time lecturer at Monash Sunway University from 2006 to 2007 . He is currently a director of O3 Solutions Sdn Bhd and SGT Konsult Sdn Bhd. 


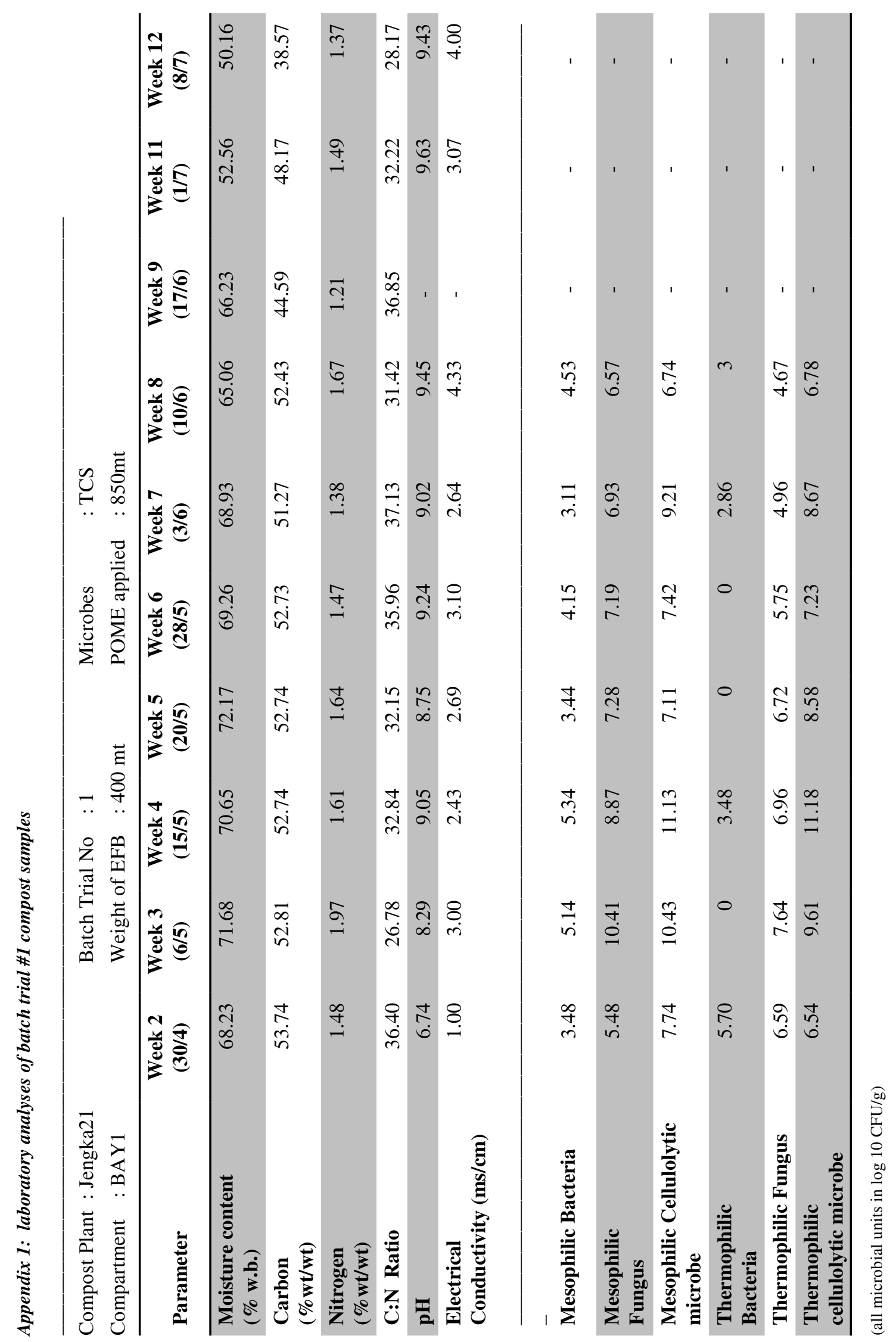

